\title{
Effects of belowground litter addition, increased precipitation and clipping on soil carbon and nitrogen mineralization in a temperate steppe
}

\author{
L. Ma ${ }^{1}$, C. Guo ${ }^{1,2}$, X. Xin ${ }^{3}$, S. Yuan ${ }^{1,2}$, and R. Wang ${ }^{1}$ \\ ${ }^{1}$ State Key Laboratory of Vegetation and Environmental Change, Institute of Botany, the Chinese Academy of Sciences, \\ Beijing, 100093, China \\ ${ }^{2}$ Graduate School of Chinese Academy of Sciences, Beijing, 100049, China \\ ${ }^{3}$ Institute of Agricultural Resources and Regional Planning, Chinese Academy of Agriculture Sciences, Beijing, \\ 100081, China
}

Correspondence to: R. Wang (wangrz@ibcas.ac.cn)

Received: 13 May 2013 - Published in Biogeosciences Discuss.: 13 June 2013

Revised: 16 October 2013 - Accepted: 21 October 2013 - Published: 18 November 2013

\begin{abstract}
Soil carbon (C) and nitrogen (N) cycling are sensitive to changes in environmental factors and play critical roles in the responses of terrestrial ecosystems to natural and anthropogenic perturbations. This study was conducted to quantify the effects of belowground particulate litter (BPL) addition, increased precipitation and their interactions on soil $\mathrm{C}$ and $\mathrm{N}$ mineralization in two adjacent sites where belowground photosynthate allocation was manipulated through vegetation clipping in a temperate steppe of northeastern China from 2010 to 2011 . The results show that BPL addition significantly increase soil $\mathrm{C}$ mineralization rate (CMR) and net $\mathrm{N}$ mineralization rate (NMR). Although increased precipitation-induced enhancement of soil CMR essentially ceased after the first year, stimulation of soil NMR and net nitrification rate continued into the second year. Clipping only marginally decreased soil CMR and NMR during the two years. There were significant synergistic interactions between BPL addition (and increased precipitation) and clipping on soil CMR and NMR, likely to reflect shifts in soil microbial community structure and a decrease in arbuscular mycorrhizal fungi biomass due to the reduction of belowground photosynthate allocation. These results highlight the importance of plants in mediating the responses of soil $\mathrm{C}$ and $\mathrm{N}$ mineralization to potentially increased BPL and precipitation by controlling belowground photosynthate allocation in the temperate steppe.
\end{abstract}

\section{Introduction}

About $75 \%$ of organic carbon (C) contained in terrestrial ecosystems and the majority of organic nitrogen $(\mathrm{N})$ is found in plant residues and soil organic matter (SOM) (Lal, 2008). Both soil organic $\mathrm{C}$ and $\mathrm{N}$ are mineralized to simple inorganic forms by a highly dynamic community of microbial decomposers (Paul, 2007; Manzoni and Porporato, 2009). SOM mineralization results in a gross release of $\mathrm{CO}_{2}$ to the atmosphere and provides most of the inorganic nutrient necessary for plant and microbial growth (Manzoni and Porporato, 2009; Xia et al., 2009; Ma et al., 2011). Therefore, soil C and $\mathrm{N}$ mineralization have important roles in the functioning of soil in nutrient cycling, structural formation and plant interactions (Wardle et al., 2004; Harris et al., 2009).

Anticipated global warming and increasing atmospheric $\mathrm{CO}_{2}$ concentration are assumed to increase primary production in semiarid grassland ecosystems (IPCC, 2007), and consequently much more plant residue will be incorporated into SOM. Soil C and $\mathrm{N}$ mineralization responses to litter addition (or substrate input) have been well documented for forest, farmland and heath ecosystems (Rinnan et al., 2008; Feng et al., 2009; Busse et al., 2009; McIntyre et al., 2009). Previous studies have shown that the amount of SOM sequestration is linearly related to plant primary production in long-term field experiments (Parton et al., 1996; Jastrow et al., 2005); however, a number of studies claim that aboveand belowground litter addition do not necessarily translate 
into increased SOM sequestration in energy-limited ecosystems, because microbial activity could be stimulated to such a degree that most or all of the added litter is decomposed rapidly (Gill et al., 2002; Xiao et al., 2007; Rinnan et al., 2008). Therefore, whether or not litter addition results in the enhancement of soil $\mathrm{C}$ and $\mathrm{N}$ mineralization in temperate steppes remains unknown.

Global climate models predict changing precipitation regimes in the future, with increasing precipitation at the mid-latitude regions (IPCC, 2007). Increased precipitation is anticipated to stimulate microbial respiration and nutrient mineralization in short-term experimental conditions, especially in arid and semi-arid ecosystems where water availability is a critical factor limiting plant and microbial growth (Sparling et al., 1995; Smith et al. 1997; Weltzin et al., 2003; Collins et al., 2008). In contrast, water-saturated soils usually limit soil $\mathrm{C}$ and $\mathrm{N}$ mineralization, and favor other process such as denitrification (Zhang and Wienhold, 2002).

Until recently, it has been the prevailing opinion that plants exert a strong control on ecosystem $\mathrm{C}$ and $\mathrm{N}$ cycling by producing litter of different quantities and qualities (Zhang et al., 2005; Jin et al., 2011). However, increasing evidence indicates that plants may exert much greater effects on soil $\mathrm{C}$ and $\mathrm{N}$ cycling than previously estimated by controlling belowground photosynthate allocation (Chapman et al., 2006; Kaiser et al., 2011). Högberg and Read (2006) reported that approximately half of the soil respiration is derived from belowground photosynthate allocation. This large photosynthate input to the soil microbial community may in turn significantly affect soil $\mathrm{C}$ and $\mathrm{N}$ cycling (Kaiser et al., 2011). For example, interrupting the photosynthates flow from the canopy leaves to the roots has led to an approximately $50 \%$ reduction of mycorrhizal fungi in beech forest, and has strongly affected soil $\mathrm{N}$ cycling (Kaiser et al., 2010, 2011). In temperate grasslands, land management practices such as heavy grazing and repeated harvesting (reducing belowground photosynthate allocation) probably significantly influences the direct impacts of belowground particulate litter (BPL) addition and increased precipitation on soil $\mathrm{C}$ and $\mathrm{N}$ mineralization. For example, BPL addition (and increased precipitation) might accelerate the mineralization process, but this effect may be partly eliminated by reducing plant belowground photosynthate allocation due to the decreases in soil dissolved organic $\mathrm{C}$ levels and water fluxes (Zhang et al., 2005; Kaiser et al., 2011). Moreover, reducing belowground photosynthate allocation may alter the effects of BPL addition and increased precipitation on soil microbial communities (especially mycorrhizal fungi), thereby partly masking their effects on soil $\mathrm{C}$ and $\mathrm{N}$ mineralization.

To examine the effects of BPL addition and increased precipitation on soil $\mathrm{C}$ and $\mathrm{N}$ mineralization under two management regimes (i.e. clipped and unclipped treatments), we conducted a field experiment in which we artificially added particulate litter to topsoil $(+60 \%)$, increased the precipitations $(+30 \%)$ and simulated heavy grazing or harvest by monthly clipping in the temperate steppe of northeastern China. We hypothesized that (1) BPL addition and increased precipitation would significantly stimulate soil $\mathrm{C}$ and $\mathrm{N}$ mineralization; and (2) there would be antagonistic effects of combined BPL addition (and increased precipitation) and clipping on soil $\mathrm{C}$ and $\mathrm{N}$ mineralization in the temperate steppe based on the above prediction.

\section{Materials and methods}

\subsection{Study site and experimental design}

This study was conducted at the Hulunber Grassland Ecosystem Observation and Research Station of the Chinese Academy of Agriculture Sciences, which is located at Xiertala farm, at the center of Hulunber steppe $\left(49^{\circ} 19^{\prime} \mathrm{N}\right.$, $120^{\circ} 02^{\prime}$ E, $628 \mathrm{~m}$ a.s.l), Inner Mongolia, China. Mean annual air temperature is between $\sim-3$ and $-1{ }^{\circ} \mathrm{C}$. The mean annual precipitation was approximately $350 \mathrm{~mm}$ for the period 1960-2000 (http://www.worldclim.com), 340.5 and $320.9 \mathrm{~mm}$ in 2010 and 2011 (http://www.climate.nm.cn), respectively. The soil in this area is classified as chestnut soil according to Chinese classification or kastanozems according to the FAO classification. The native vegetation was dominated by perennial grass Stipa baicalensis; other abundant plant species include Leymus chinensis (Trin.) Tzvel., Artemisia frigida Willd., Artemisia tanacetifolia Linn. and Serratula centauroides. Total vegetation ground cover ranges from 60 to $75 \%$.

The experimental area with fairly uniform vegetation was selected in May 2010, and was divided into two sites. Vegetation was removed by clipping in one of these sites (clipped), and the other site was left unclipped (control). The distance between the two adjacent sites was $8 \mathrm{~m}$, and the two sites were identical in soil and plant community properties before the experiment began (Table 1). Forty-eight $2 \times 2 \mathrm{~m}^{2}$ plots were established, with 24 plots in the control site and the others in the clipping site. Within the two un-replicated clipping treatment blocks, ambient (unmanipulated control), belowground particulate litter (BPL) addition treatment, increased precipitation treatment and their combination were applied following a randomized block design, with each treatment replicated six times. The distance between any two adjacent plots was $2 \mathrm{~m}$.

BPL treatments involved the addition of particulate litter to the surface soil layer $(0-10 \mathrm{~cm})$ at $720 \mathrm{~g} \mathrm{~m}^{-2}$. Because the ecosystem total plant above- and belowground biomass was about $1200 \mathrm{~g} \mathrm{~m}^{-2} \mathrm{yr}^{-1}$ (Ma et al., 2012), these litter additions correspond to increases in ecosystem biomass production of $60 \%$. The addition rate was designed to approximate projected increases in NPP of temperate steppes by 26$61 \%$ under $\mathrm{CO}_{2}$ concentration doubling ( $\mathrm{Gao}$ and $\mathrm{Yu}, 1998$ ). Senescent plant biomass was harvested from an adjacent field, air-dried and milled to $1-2 \mathrm{~mm}$ before use. The $\mathrm{C}$ and $\mathrm{N}$ 
Table 1. Soil and plant community properties (mean \pm SE) of control and clipping sites before treatment.

\begin{tabular}{llll}
\hline & Term & Control site & Clipping site \\
\hline Soil property & SOM $\left(\mathrm{g} \mathrm{kg}^{-1}\right)$ & $53.2 \pm 1.3^{\mathrm{NS}}$ & $52.9 \pm 1.5$ \\
$(0-10 \mathrm{~cm})$ & $\mathrm{TN}\left(\mathrm{g} \mathrm{kg}^{-1}\right)$ & $2.61 \pm 0.05^{\mathrm{NS}}$ & $2.63 \pm 0.06$ \\
& $\mathrm{pH}$ & $7.7 \pm 0.08^{\mathrm{NS}}$ & $7.73 \pm 0.06$ \\
& Soil bulk density $\left(\mathrm{g} \mathrm{cm}^{-3}\right)$ & $1.37 \pm 0.14^{\mathrm{NS}}$ & $1.36 \pm 0.12$ \\
Plant community & Biomass $\left(\mathrm{g} \mathrm{m}^{-2}\right)$ & $1113 \pm 51.33^{\mathrm{NS}}$ & $1087 \pm 61.59$ \\
property & Richness & 31 & 31 \\
& GB : BB & $0.48 \pm 0.02^{\mathrm{NS}}$ & $0.46 \pm 0.03$ \\
& Vegetation cover $(\%)$ & $70 \pm 5.22^{\mathrm{NS}}$ & $68 \pm 4.87$ \\
\hline
\end{tabular}

Significant differences between sites are reported from one-way ANOVA as NS, $P>0.05$; SOM, soil organic matter; TN, total N; GB : BB, grass: forb biomass.

contents, the $\mathrm{C}: \mathrm{N}$ ratio, and the $\mathrm{P}$ and lignin contents of the SOM were $40.33 \%$ (standard error $(\mathrm{SE})=2.64 \% ; n=6$ ), $0.32 \%(\mathrm{SE}=0.03 \% ; \mathrm{n}=6), 144.6(\mathrm{SE}=13.2 \% ; n=6)$, $0.025 \%(\mathrm{SE}=0.002 \% ; n=6)$ and $20.41 \%(\mathrm{SE}=1.24 \%$; $n=6$ ), respectively. We expected to add the particulate litter to the upper soil layers without drastically damaging the root systems. For this purpose, we carefully used sharp forks to loosen the surface soil $(10 \mathrm{~cm})$, and a predetermined quantity of particulate litter was gradually and homogeneously added to the soil in the $0-10 \mathrm{~cm}$ layer. The soil pores were carefully filled with soil and gently compacted by hand. To create consistent soil disturbance across treatments, the plots with no BPL addition were processed in the same manner as the plots that received BPL addition (Ma et al., 2012).

For increased precipitation, treatment simulated a $30 \%$ increase in growing season precipitation from 2010 to 2012, as climate models predict that annual precipitation will increase by $30-100 \mathrm{~mm}$ this century in the steppe ( $\mathrm{Ni}$ and Zhang, 2000). Two open-top iron boxes (length $85 \mathrm{~cm} \times$ width $71.5 \mathrm{~cm} \times$ height $15 \mathrm{~cm}$ ) were set outside each increased precipitation plot (Fig. 1). The base area of each iron box was approximately $15 \%$ of each plot $\left(2 \times 2 \mathrm{~m}^{2}\right)$. A circular hole $(1.5 \mathrm{~cm}$ inner diameter) was punched on one side of the box (facing the plot) and a rubber water pipe was connected to the hole. The rain falling into the boxes rapidly flowed to the increased precipitation plots by these water pipes. Each pipe was arranged in an $S$ shape on the ground and was perforated by a series of small holes so that the additional precipitation was evenly applied to the plots.

In the clipping site, plants were thoroughly clipped every month during the two growing seasons in order to interrupt the photosynthates flow from the canopy to the roots. In this water- and nutrient-limited temperate steppe (grass: forb biomass $=0.48$ ), the recovery and regrowth of plants, especially forb species, are very slow after clipping (Zhu et al., 2004). Moreover, removal of aboveground biomass actually increases resource allocation to recover its aboveground photosynthetic organs (Atkinson, 1991). Therefore, monthly clipping can significantly decrease belowground photosyn- thate allocation in this study. At the end of each growing season, the clipped plants were returned to their respective plots to maintain natural litter levels.

\subsection{Soil samplings}

Four soil cores ( $5 \mathrm{~cm}$ inner diameter, $10 \mathrm{~cm}$ length) were randomly collected from the topsoil $(0-10 \mathrm{~cm})$ of each plot in late June, mid-August and late September in 2010 and 2011. The four replicates were mixed to get one composite sample, and then each composite sample was sieved using a $2 \mathrm{~mm}$ sieve. Two subsamples of the sieved soil from each composite sample were obtained; one was kept in the refrigerator at $4{ }^{\circ} \mathrm{C}$ for routine analyses and the other at $-70{ }^{\circ} \mathrm{C}$ for phospholipid fatty acids (PLFAs) analysis.

\subsection{Soil microclimate and nutrient measurements}

Soil temperature and moisture measurements were conducted one day after the rainfall events. Gravimetric soil moisture was measured by oven-drying samples at $105^{\circ} \mathrm{C}$ for $24 \mathrm{~h}$. Soil temperature at the depth of $10 \mathrm{~cm}$ was measured using a temperature probe connected to an infrared gas analyzer (Li-6400, Li-Cor, USA). Two measurements each were taken between 8.00 and 9.00 a.m. in late May, late June, mid-July, late July, mid-August, late August, mid-September in 2010 and 2011; the averages of the two measures were stored as the mean value per plot.

Concentrations of inorganic $\mathrm{N}\left(\left[\mathrm{NH}_{4}^{+}-\mathrm{N}\right]\right.$ and $\left.\left[\mathrm{NO}_{3}^{-}-\mathrm{N}\right]\right)$ in the filtered extracts were determined using a flow injection autoanalyzer (FIAstar 5000 Analyzer, Foss Tecator, Denmark). Soil extracts from the fresh samples were obtained by shaking soil samples with $60 \mathrm{~mL} 0.5 \mathrm{M} \mathrm{K}_{2} \mathrm{SO}_{4}$ for $30 \mathrm{~min}$. The extracts were filtered through $0.45 \mu \mathrm{m}$ filters and their extractable organic $\mathrm{C}$ analyzed by dichromate digestion as described by Lovell et al. (1995). The data of C in the unfumigated soil extracts were used as soil dissolved organic C (DOC) (Liu et al., 2010). The soil light SOM and heavy SOM were determined using the density fractionation method (Sollins et al., 1984). 


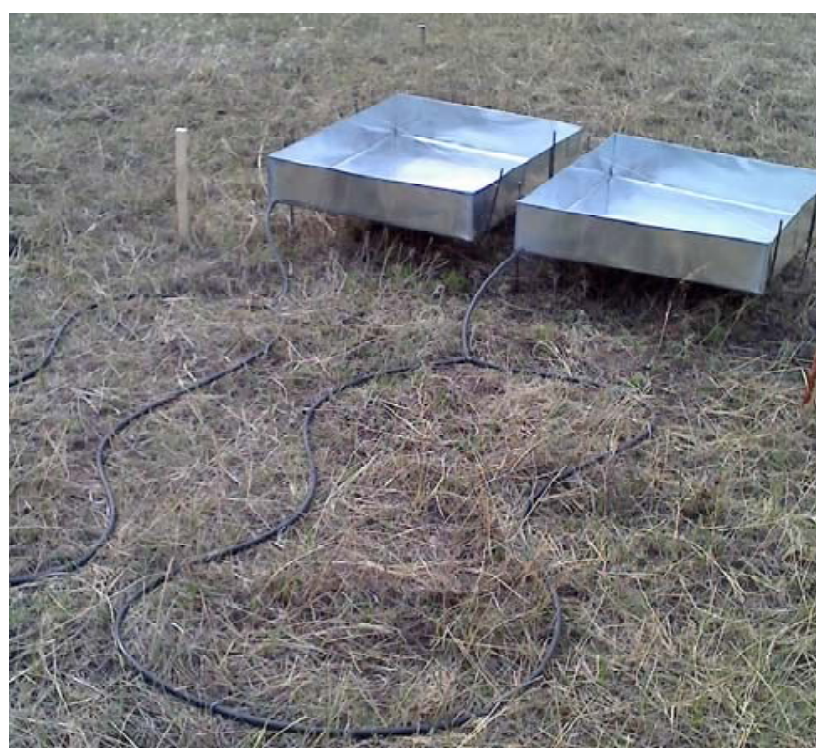

Fig. 1. The picture of increased precipitation treatments in a temperate steppe of northeastern China.

\subsection{Soil microbial community}

Phospholipid fatty acids (PLFAs) were extracted from $8.0 \mathrm{~g}$ (dry weight equivalent) soils using a procedure described by Bossio and Scow (1998). The separation and identification of extracted PLFAs were carried out according to the standard protocol of the Sherlock Microbial Identification System $V_{4.5}$ (MIDI) and a Gas Chromatograph (Agilent 6850, USA). Methyl nonadecanoate fatty acid (19:0) was used as internal standard. The fatty acid nomenclature used in this study is as that defined by Bossio and Scow (1998). The fatty acids a13:0, i14:0, i15:0, i16:0, i17:0 and a17:0 were chosen to represent the gram-positive bacteria; $16: 1 \omega 7 \mathrm{c}, 17: 1 \omega 8 \mathrm{c}$, 18:1 $\omega 5 \mathrm{c}, 18: 1 \omega 9 \mathrm{t}, 17: 0 \mathrm{cy}$ and 19:0cy were chosen to represent the gram-negative bacteria (Frostegård et al., 1993, $1996)$; three fatty acids $(16: 1 \omega 5 \mathrm{c}, 18: 2 \omega 6,9 \mathrm{c}$ and $18: 1 \omega 9 \mathrm{c})$ were chosen to represent the fungal group (Olsson et al., 1998). The PLFA 16:1 $\omega 5$ was used as an indicator of arbuscular mycorrhizal fungi (Olsson et al., 1999).

\subsection{Soil $\mathrm{C}$ and $\mathrm{N}$ mineralization}

The soil $\mathrm{C}$ mineralization rate, i.e. the microbial respiration, was estimated by determining $\mathrm{CO}_{2}$ evolution over a $2 \mathrm{wk}$ incubation period. Respired $\mathrm{CO}_{2}$ was then captured in $5.0 \mathrm{~mL}$ of $0.5 \mathrm{M} \mathrm{NaOH}$ contained in a beaker suspended inside each Mason jar. The $\mathrm{NaOH}$ solution was removed and titrated to determine the amount of $\mathrm{CO}_{2}$ evolved ( $\mathrm{Hu}$ and van Bruggen, 1997; Ma et al., 2012).

The in situ soil $\mathrm{N}$ mineralization method used was similar to that described by Raison et al. (1987). A pair of PVC tubes $(12 \mathrm{~cm}$ in length, $5 \mathrm{~cm}$ in diameter) was inserted vertically
$10 \mathrm{~cm}$ deep into the soil layer to incubate a soil volume in the absence of plant uptake. One soil core from each pair was taken as the unincubated sample to measure initial $\left[\mathrm{NH}_{4}^{+}\right.$$\mathrm{N}]$ and $\left[\mathrm{NO}_{3}^{-}-\mathrm{N}\right]$ concentrations by a flow injection autoanalyzer (FIAstar 5000 Analyzer, Foss Tecator, Denmark). The other core was incubated in situ, lasting an average of $30 \mathrm{~d}$ (min. $27 \mathrm{~d}$, max. $2 \mathrm{~d}$ ) in capped tubes to prevent leaching with rainfall. Soil $\left[\mathrm{NH}_{4}^{+}-\mathrm{N}\right]$ and $\left[\mathrm{NO}_{3}^{-}-\mathrm{N}\right]$ concentrations in the incubated samples were also analyzed after incubation. Net $\mathrm{N}$ mineralization and net nitrification rates were calculated as the changes in $\left[\mathrm{NH}_{4}^{+}-\mathrm{N}\right]$ and $\left[\mathrm{NO}_{3}^{-}-\mathrm{N}\right]$ concentrations in the initial and incubated samples (Wang et al., 2006).

\subsection{Statistical analysis}

Monthly mean values used in this study were averaged from six replicates in the same month. Repeated measures ANOVAs were used to examine the temporal (inter- or intraannual) variations and the effects of BPL addition, increased precipitation and clipping on soil microclimate, soil DOC and inorganic $\mathrm{N}$, soil microbial biomass, microbial community, and soil $\mathrm{C}$ and $\mathrm{N}$ mineralization. Between-subject effects were evaluated as BPL addition, increased precipitation, clipping and their interactions, and within-subject effects were year (or measuring times within season) and its interactions with BPL addition, increased precipitation and clipping. Stepwise multiple linear analyses were used to determine the relationships of soil $\mathrm{C}$ mineralization rate (net $\mathrm{N}$ mineralization and net nitrification rates) with control factors. Multiple comparisons were also performed to permit separation of effect means using the least significant difference test at a significance level of $P<0.05$. Data management and statistical analyses were performed using SPSS 17.0 software (SPSS, Chicago, IL, USA).

\section{Results}

\subsection{Soil microclimate}

Belowground particulate litter (BPL) addition showed no effect on soil temperature and moisture $(0-10 \mathrm{~cm})$ during the two growing seasons (Fig. 2a, C). Increased precipitation elevated soil moisture by 12 and $9 \%(P<0.05$, Fig. 2 c; one-way ANOVAs) in 2010 and 2011, respectively. Clipping increased top layer soil temperature by 0.6 and $0.8^{\circ} \mathrm{C}$ $(P<0.05$, Fig. 2b; one-way ANOVAs) in 2010 and 2011, respectively. BPL addition interacted with increased precipitation to affect soil moisture $(P<0.01$, Fig. 2 c, Table 2 ; repeated measures ANOVAs), because increased precipitation treatments significantly increased soil moisture under ambient litter conditions, but had a minor effect under BPL addition plots. 
Table 2. Results ( $F$ values) of repeated measures ANOVAs on the effects of belowground particulate litter addition (L), increased precipitation $(\mathrm{P})$ clipping $(\mathrm{C})$, and year $(\mathrm{Y})$, and their interactions on soil temperature (ST) and moisture (SM), soil dissolved organic C (DOC) and inorganic N (IN), soil total PLFAs (TP), soil fungal PLFAs (F), gram-negative and gram-positive bacterial PLFAs $\left(\mathrm{G}^{-}, \mathrm{G}^{+}\right)$, the ratio of fungal to bacterial PLFAs (F:B), arbuscular mycorrhizal fungi PLFAs (AMF), soil C mineralization rate (CMR), net $\mathrm{N}$ mineralization rate (NMR) and net nitrification rate (NNR).

\begin{tabular}{|c|c|c|c|c|c|c|c|c|c|c|c|c|c|}
\hline & ST & SM & DOC & IN & $\mathrm{TP}$ & $\mathrm{F}$ & $\mathrm{G}^{-}$ & $\mathrm{G}^{+}$ & $\mathrm{F}: \mathrm{B}$ & AMF & CMR & NMR & NNR \\
\hline $\mathrm{L}$ & 0.45 & 5.66 & 74.56 & 7.76 & 189.3 & 227.96 & 33.54 & 2.36 & 29.62 & 78.03 & 102.43 & 8.87 & 1.67 \\
\hline $\mathrm{P}$ & 2.04 & 24.47 & 35.74 & 67.72 & 2.8 & 23.57 & 5.31 & 31.84 & 3.48 & 5.05 & 15.63 & 16.64 & 16.76 \\
\hline $\mathrm{C}$ & 30.33 & 2.51 & 198.56 & 7.03 & 1.65 & 103.23 & 1.79 & 1.78 & 148.14 & 543.49 & 13.04 & 7.34 & 0.82 \\
\hline $\mathrm{L} \times \mathrm{P}$ & 0.21 & 6.48 & 0.01 & 3.29 & 0.28 & 4.04 & 1.03 & 0.77 & 4.19 & 7.78 & 6.86 & 7.58 & 8.28 \\
\hline $\mathrm{L} \times \mathrm{C}$ & 0.03 & 1.43 & 0.11 & 4.01 & 0.19 & 7.34 & 67.93 & 2.24 & 7.14 & 33.67 & 9.98 & 4.22 & 0.15 \\
\hline $\mathrm{P} \times \mathrm{C}$ & 0.23 & 2.04 & 0.04 & 3.98 & 0.05 & 6.99 & 4.03 & 6.93 & 29.36 & 0.15 & 13.72 & 4.72 & 0.31 \\
\hline $\mathrm{L} \times \mathrm{P} \times \mathrm{C}$ & 0.31 & 2.11 & 0.01 & 0.29 & 0.28 & 2.32 & 1.35 & 3.93 & 4.03 & 2.87 & 6.07 & 0.47 & 0.01 \\
\hline Y & 19.97 & 17.06 & 40.02 & 29.59 & 0.25 & 14.64 & 6.84 & 3.68 & 4.33 & 1.05 & 3.32 & 1.79 & 3.17 \\
\hline $\mathrm{Y} \times \mathrm{L}$ & 0.08 & 0.27 & 2.66 & 3.96 & 0.27 & 2.43 & 4.63 & 1.72 & 6.95 & 5.72 & 2.63 & 1.17 & 0.08 \\
\hline $\mathrm{Y} \times \mathrm{P}$ & 1.01 & 1.64 & 0.15 & 6.24 & 0.56 & 1.21 & 4.42 & 6.03 & 4.32 & 1.15 & 3.35 & 2.35 & 0.01 \\
\hline $\mathrm{Y} \times \mathrm{C}$ & 2.09 & 1.51 & 2.65 & 3.88 & 0.02 & 2.25 & 1.22 & 1.04 & 0.41 & 8.45 & 3.96 & 0.45 & 0.30 \\
\hline $\mathrm{Y} \times \mathrm{L} \times \mathrm{P}$ & 0.12 & 0.84 & 0.04 & 1.05 & 0.26 & 0.40 & 0.97 & 3.77 & 5.65 & 0.35 & 0.74 & 0.04 & 0.05 \\
\hline $\mathrm{Y} \times \mathrm{L} \times \mathrm{C}$ & 0.08 & 0.19 & 0.62 & 0.83 & 0.20 & 0.53 & 0.84 & 1.23 & 2.76 & 4.65 & 1.04 & 0.01 & 0.25 \\
\hline $\mathrm{Y} \times \mathrm{P} \times \mathrm{C}$ & 0.03 & 0.15 & 0.01 & 1.07 & 0.01 & 1.58 & 0.63 & 2.21 & 1.01 & 0.03 & 3.95 & 1.03 & 0.12 \\
\hline $\mathrm{Y} \times \mathrm{L} \times \mathrm{P} \times \mathrm{C}$ & 0.07 & 0.83 & 0.02 & 0.73 & 0.02 & 2.65 & 0.38 & 0.83 & 2.13 & 1.34 & 0.65 & 0.05 & 0.07 \\
\hline
\end{tabular}

Significance was represented in bold.

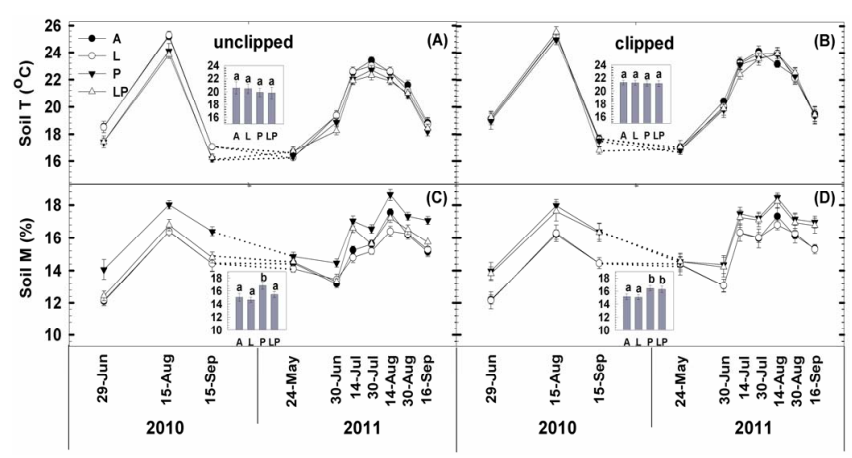

Fig. 2. Seasonal variations of soil temperature $(T)$ and soil moisture (M) at $10 \mathrm{~cm}$ depth in response to belowground particulate litter addition $(+60 \%)$, increased precipitation $(+30 \%)$ and clipping during the two growing seasons in the temperate steppe of northeastern China (Fig. 2A, C from Ma et al., 2012). Insets represent the two seasonal mean values of soil temperature and moisture. Vertical bars indicate standard error of means $(n=6)$. Different lowercase letters indicate statistically significant differences $(P<0.05)$. $\mathrm{A}=$ ambient condition, $\mathrm{L}=$ belowground particulate litter addition, $\mathrm{P}=$ increased precipitation, $\mathrm{LP}=$ combined belowground particulate litter addition and increased precipitation.

\subsection{Treatment effects on control factors over soil $\mathrm{C}$ and $\mathrm{N}$ mineralization}

BPL addition significantly increased soil dissolved organic C (DOC) by 12.8 and $9.1 \%(P<0.01$, Fig. 3a), total PLFAs by 22.8 and $28.1 \%(P<0.001$, Fig. 4a), fungal PLFAs by 24.5 and $29.5 \%(P<0.001$, Fig. $4 \mathrm{c})$, gram-negative bacterial PLFAs by 48.2 and $52.2 \%(P<0.001$, Fig. 4 e $)$, arbus- cular mycorrhizal fungal (AMF) PLFAs by 16.2 and $24.2 \%$ $(P<0.001$, Fig. 4k) in 2010 and 2011, and slightly increased soil light organic matter by $9.5 \%$ after two years $(P<0.1$, Fig. 3e). However, BPL addition showed no effect on soil inorganic N (IN), soil heavy organic matter, gram-positive bacterial PLFAs, or the ratio of fungal to bacterial PLFAs $(\mathrm{F}: \mathrm{B})$ in the two years.

Increased precipitation significantly reduced soil IN by $8.3 \%(P<0.05)$ and $20 \%(P<0.01$, Fig. $3 c)$ in 2010 and 2011 , respectively. In addition, increased precipitation only increased soil F : B by 23.1 and $22.8 \%(P<0.001$, Fig. $4 \mathrm{i})$ in August and September 2011.

Clipping significantly reduced soil DOC by 15.3 and $20 \%$ $(P<0.001$, Fig. 3b), fungal PLFAs by 14.5 and $16.6 \%$ $(P<0.001$, Fig. $4 \mathrm{~d}), \mathrm{F}: \mathrm{B}$ by 11.7 and $15 \%(P<0.01$, Fig. 4j), AMF by 31.8 and $36.2 \%(P<0.001$, Fig. 41$)$ in 2010 and 2011, and decreased soil light organic matter by $19 \%$ after two years $(P<0.05$, Fig. 3f $)$. Moreover, clipping increased soil IN by 9.8 and $7.7 \%$ in the two years $(P<0.05$, Fig. 3d). However, no main effect of clipping on soil total PLFAs, gram-negative bacterial PLFAs, and gram-positive bacterial PLFAs were detected across the two years.

There were significant interactive effects between clipping and BPL addition (and increased precipitation) on soil IN, fungal PLFAs, gram-negative and gram-positive bacterial PLFAs, F: B, and AMF $(P<0.05$, Figs. $3 \mathrm{~d}, 4 \mathrm{~d}, 4 \mathrm{f}$, $4 \mathrm{~h}, 4 \mathrm{j}, 4 \mathrm{l}$, Table 2; repeated measures ANOVAs). Moreover, BPL addition interacted with increased precipitation to affect soil fungal PLFAs, gram-negative bacterial PLFAs, and $\mathrm{F}$ : $\mathrm{B}$ $(P<0.05$, Figs. $4 \mathrm{c}$, e, 3 i, Table 2$)$. 


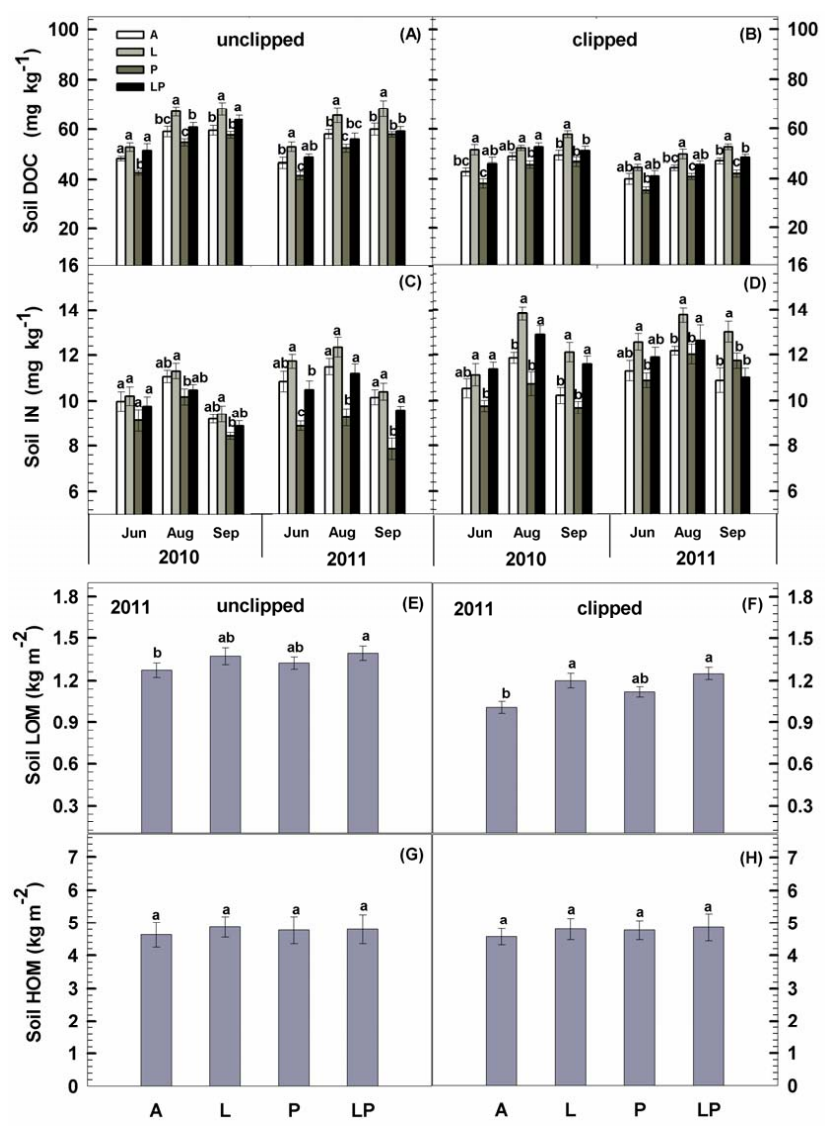

Fig. 3. Responses of soil dissolved organic C (DOC), inorganic $\mathrm{N}$ (IN), soil light organic matter (LOM) and heavy organic matter $(\mathrm{HOM})$ to belowground particulate litter addition $(+60 \%)$, increased precipitation $(+30 \%)$ and clipping in the temperate steppe of northeastern China. Vertical bars indicate standard error of means $(n=6)$. Different lowercase letters indicate statistically significant differences $(P<0.05)$. See Fig. 2 for abbreviations.

\subsection{Control factors over soil $\mathrm{C}$ and $\mathrm{N}$ mineralization at the temporal and spatial scales}

In general, soil $\mathrm{C}$ mineralization rate (CMR), net $\mathrm{N}$ mineralization rate (NMR) and net nitrification (NNR) showed pronounced seasonal variations during the two growing seasons with higher values in summer and lower values in spring and autumn (Fig. 5a-f). Across the two growing seasons, stepwise multiple regression analysis of soil CMR (NMR or NNR) with control factors indicating the combination of soil temperature (partial $r^{2}=0.54$ in CMR, partial $r^{2}=0.47$ in NMR, partial $r^{2}=0.53$ in NNR; $\left.P<0.001\right)$ and soil moisture (partial $r^{2}=0.32$ in CMR, partial $r^{2}=0.35$ in NMR, partial $r^{2}=0.30$ in NNR; $P<0.001$ ) explained 86,82 and $83 \%$ of the seasonal variations of soil CMR, NMR and NNR. These results suggest that all the concurrent seasonal variations of soil temperature and moisture contributed to the temporal fluctuations of soil $\mathrm{C}$ and $\mathrm{N}$ mineralization.
Across the 48 plots, stepwise multiple regression analyses demonstrated that $67.2 \%$ of the spatial variation in soil CMR could be explained by seasonal mean soil total PLFAs, soil moisture, F : B and AMF in 2010 (Table 3). In 2011, soil total PLFAs, F: B, soil moisture, AMF and IN were responsible for $87 \%$ of the spatial variation in CMR. Sixty-five percent of the spatial variation in soil NMR could be explained by seasonal mean soil moisture, total PLFAs, F : B and AMF in 2010. In 2011, soil moisture, total PLFAs and F: B together accounted for $61 \%$ in NMR (Table 3). Dissimilar to soil CMR and NMR, soil moisture alone contributed to $16.4 \%$ of the spatial variation in soil NNR in 2010. In 2011, $33 \%$ of the spatial variability in NNR was attributable to the combination of soil moisture, total PLFAs and soil temperature (Table 3).

\subsection{Main and interactive effects on soil $\mathbf{C}$ and $\mathrm{N}$ mineralization}

During the two years, BPL addition increased CMR by 15.9 and $15.1 \%(P<0.001$, Fig. 5a), NMR by 7.3 and $9.2 \%$ $(P<0.05$, Fig. 5c) in 2010 and 2011, whereas there was no effect on soil NNR (Fig. 5E). Increased precipitation only increased CMR by $10 \%(P<0.05$, Fig. 5a) in 2010, but it increased soil NMR by 9.3 and $12.6 \%(P<0.05$, Fig. 5 c $)$, NNR by 14 and $11.7 \%(P<0.01$, Fig. 5 e $)$ in the two years, respectively. Clipping slightly decreased soil CMR by $6.6 \%$ and $6 \%(P<0.1$, Fig. 5b), NMR by 6.1 and $5.9 \%(P<0.1$, Fig. 5d) in 2010 and 2011, but showed no effect on soil NNR. BPL addition (and increased precipitation) interacted with clipping to affect soil CMR and NMR, as BPL addition (and increased precipitation) showed greater effects on soil CMR and NMR in clipped plots than in unclipped plots $(P<0.05$; Fig. 5b, d, f, Table 2; repeated measures ANOVAs). In addition, significant interactive effects between BPL addition and increased precipitation on the soil CMR, NMR and NNR, in that the increases in soil CMR (NMR or NNR) were significantly smaller than would be expected if the two factors acted additively during the two growing seasons $(P<0.01$; Fig. 5a, c, e, Table 2).

\section{Discussion}

In general, belowground particulate litter (BPL) addition caused sustained increases in the soil $\mathrm{C}$ mineralization rate (CMR) and net $\mathrm{N}$ mineralization rate (NMR) as expected, but did not affect net nitrification rate (NNR) during the two growing seasons (Fig. 5a, c, e). The rapid increase in soil organic matter decomposition was possibly because BPL addition increases soil fertility and supplies greater energy for soil biota, and consequently stimulates significant increase in microbial activity. These results are supported by observations in other ecosystems (Carter et al., 2003; Tu et al., 2006; Xiao et al., 2007). The findings indicate that the energy 
Table 3. Results of stepwise multiple regression analyses. Dependent variables: seasonal mean soil C mineralization rate (CMR, $\mathrm{mg} \mathrm{kg}^{-1} \mathrm{~d}^{-1}$ ), soil net $\mathrm{N}$ mineralization rate (NMR, $\mathrm{mg} \mathrm{kg}^{-1} \mathrm{~d}^{-1}$ ) and soil net nitrification rate $\left(\mathrm{NNR}, \mathrm{mg} \mathrm{kg}^{-1} \mathrm{~d}^{-1}\right)$; independent variables: seasonal mean total PLFAs ( $\mathrm{nmol} \mathrm{g}^{-1}$ ), the ratio of soil fungal to bacterial PLFAs (F:B), arbuscular mycorrhizal fungi (AMF, nmol ${ }^{-1}$ ), soil temperature $\left(\mathrm{ST},{ }^{\circ} \mathrm{C}\right.$ ) and moisture $(\mathrm{SM}, \%)$, soil inorganic $\mathrm{N}$ (IN, $\left.\mathrm{mg} \mathrm{kg}^{-1}\right)$. Negative values of parameter estimate refer to negative relationships between the examined dependent variables and the independent variables.

\begin{tabular}{|c|c|c|c|c|}
\hline & $\begin{array}{l}\text { Variable } \\
\text { entered }\end{array}$ & $\begin{array}{r}\text { Parameter } \\
\text { estimate }\end{array}$ & Partial $r^{2}$ & Probability \\
\hline \multicolumn{5}{|l|}{2010} \\
\hline \multirow[t]{4}{*}{ CMR } & Total PLFAs & 0.865 & 0.345 & 0.000 \\
\hline & SM & 1.944 & 0.194 & 0.000 \\
\hline & $\mathrm{F}: \mathrm{B}$ & -78.098 & 0.073 & 0.002 \\
\hline & AMF & -0.601 & 0.060 & 0.003 \\
\hline \multirow[t]{2}{*}{ NMR } & SM & 0.042 & 0.272 & 0.000 \\
\hline & Total PLFAs & 0.002 & 0.156 & 0.000 \\
\hline \multirow[t]{2}{*}{$F: B$} & -1.828 & 0.124 & 0.000 & \\
\hline & $\mathrm{AMF}$ & -0.083 & 0.102 & 0.001 \\
\hline NNR & SM & 0.039 & 0.164 & 0.004 \\
\hline \multicolumn{5}{|l|}{2011} \\
\hline CMR & Total PLFAs & 1.013 & 0.370 & 0.000 \\
\hline \multirow{4}{*}{$\mathrm{F}: \mathrm{B}$} & -52.839 & 0.245 & 0.000 & \\
\hline & SM & 3.938 & 0.134 & 0.000 \\
\hline & AMF & -0.103 & 0.068 & 0.007 \\
\hline & IN & 0.085 & 0.053 & 0.046 \\
\hline \multirow[t]{2}{*}{ NMR } & SM & 0.126 & 0.258 & 0.000 \\
\hline & Total PLFAs & 0.002 & 0.243 & 0.000 \\
\hline$F: B$ & -0.817 & 0.109 & 0.001 & \\
\hline \multirow[t]{3}{*}{ NNR } & SM & 0.074 & 0.164 & 0.004 \\
\hline & Total PLFAs & 0.007 & 0.095 & 0.020 \\
\hline & ST & 0.038 & 0.069 & 0.040 \\
\hline
\end{tabular}

limitation of soil microorganisms in the temperate steppe and may have some long-term implications to soil $\mathrm{C}$ and $\mathrm{N}$ sequestration. The greater BPL addition to soils only slightly increased soil light organic matter (with a small size and rapid turnover) rather than heavy organic matter (with a large size but slow turnover) after the two years (Fig. 3e, g) suggesting that mineral soils in the temperate steppe have a limited capacity to accumulate mineral component of the soil (Six et al., 2002; Stewart et al., 2007; Chung et al., 2008).

There have been many reports showing the positive responses of soil $\mathrm{C}$ and $\mathrm{N}$ mineralization to water addition (or increased precipitation) in water-limited temperate ecosystems in short- and long-term field experiments (Wang et al., 2006; Xiao et al., 2007; Kim et al., 2011). In contrast, we found increased precipitation only increased soil CMR in the first year, but not in the second year (Fig. 5a). Some reasons have probably led to the decreases in the water sensitivity of soil CMR as the increased precipitation progresses. Stepwise multiple regression analyses demonstrated that soil CMR was positively related to inorganic $\mathrm{N}$ content, and was negatively related to soil F: B at spatial scales in 2011. On the one hand, the relatively lower soil inorganic $\mathrm{N}$ levels following increased precipitation (Fig. 3c) may gradually contribute to $\mathrm{N}$ limitation for soil microbial activity due to the uptake of plant (Kaye and Hart, 1997; Hu et al., 2001). On the other hand, the increases in soil F: B in the second year (Fig. 4i) under increased precipitation treatments probably alter the decomposition process from a faster bacterial-based channel to a slower fungal-based channel (Jastrow et al., 1998; Zhang et al., 2005; Ma et al., 2012). Fungal-dominated soils have slow $\mathrm{C}$ turnover rates because fungi incorporate more $\mathrm{C}$ into biomass than bacteria. Some studies documented that the fungal storage of $\mathrm{C}$ from plant litter was 26 times greater than the corresponding bacterial storage of C (Suberkropp and Weyers, 1996, Six et al., 2002). Additionally, fungal hyphae have long been recognized to enmesh soil microaggregates into macroaggregates (Jastrow et al., 1998; Bossuyt et al., 2001), which could facilitate soil organic matter pool protection and stabilization in the long term (Bailey et al., 2002).

It is interesting in our study that, although the waterinduced enhancement of soil CMR essentially ceased after the first year, stimulation of soil NMR and NNR continued into the second year (Fig. 5c, e). A possible explanation for this result is likely because of the changes in plant quality. We found that the decreases in plant $\mathrm{C}: \mathrm{N}$ under increased precipitation treatments in the same study (Ma et al., 


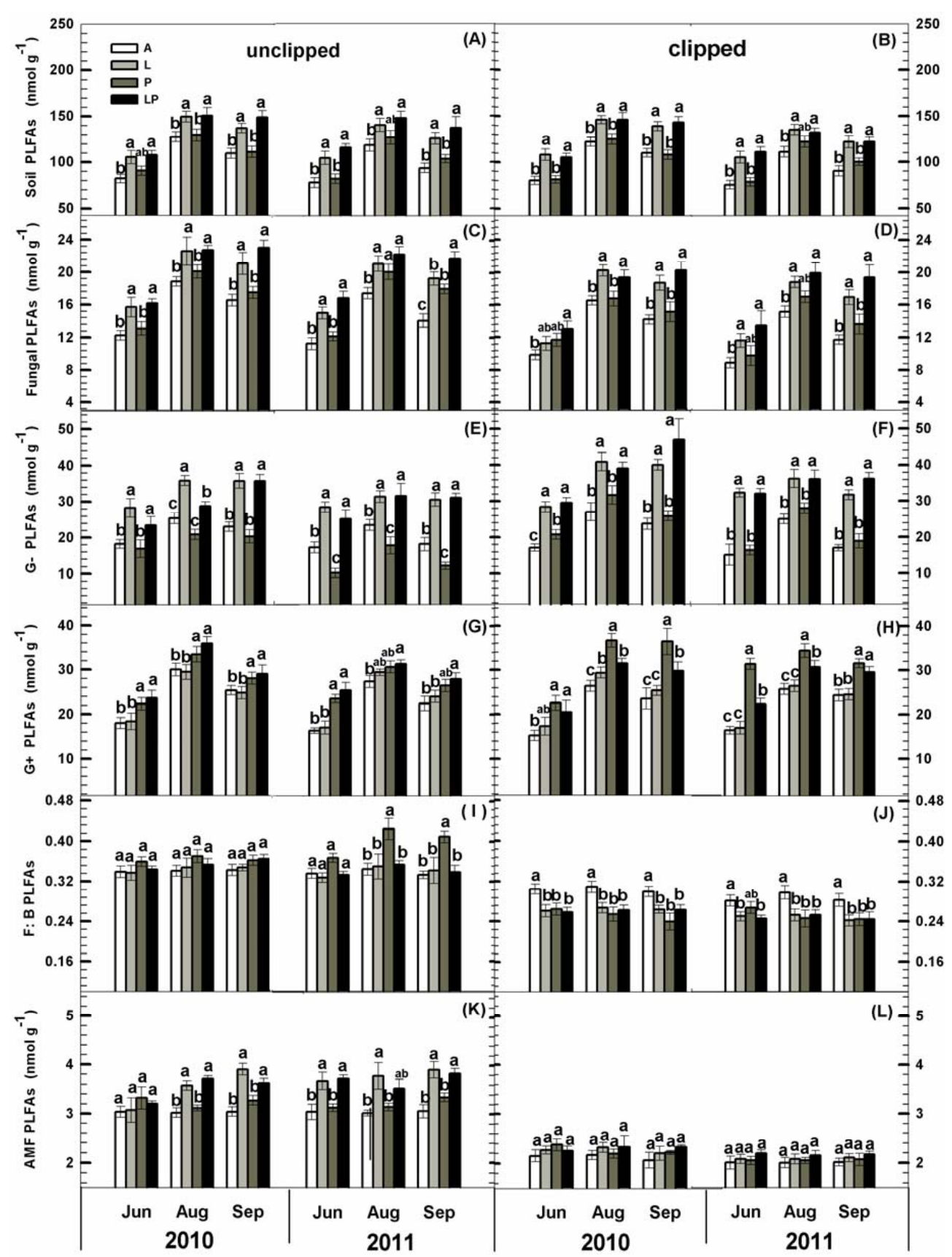

Fig. 4. The soil total phospholipid fatty acids (PLFAs), fungal PLFAs, gram-negative bacterial $\left(\mathrm{G}^{-}\right)$PLFAs, gram-positive bacterial $\left(\mathrm{G}^{+}\right)$ PLFAs, the ratio of fungal to bacterial PLFAs (F : B) and arbuscular mycorrhizal fungi PLFAs (AMF) as influenced by belowground particulate litter addition $(+60 \%)$, increased precipitation $(+30 \%)$ and clipping in the temperate steppe of northeastern China (Fig. 4A, K from Ma et al., 2012). Values show the monthly means in 2010 and 2011. Vertical bars indicate standard error of means $(n=6)$. Different lowercase letters indicate statistically significant differences $(P<0.05)$. See Fig. 2 for abbreviations.

2012) could contribute to a large quantity of lower $\mathrm{C}: \mathrm{N}$ ratio residues incorporating into soil organic matter, and then increasing $\mathrm{N}$ release during decomposition process (Aber et al., 1998; Boggs et al., 2000).

BPL addition (and increased precipitation) and land cover change may potentially trigger complex interactive influ- ences on ecosystem functioning. However, contrary to our expectation, there were significant synergistic interactions (amplifying effects) between clipping and BPL addition (and increased precipitation), because BPL addition (and increased precipitation) exerted more effects on soil CMR and NMR under clipped plots than unclipped plots. Several 


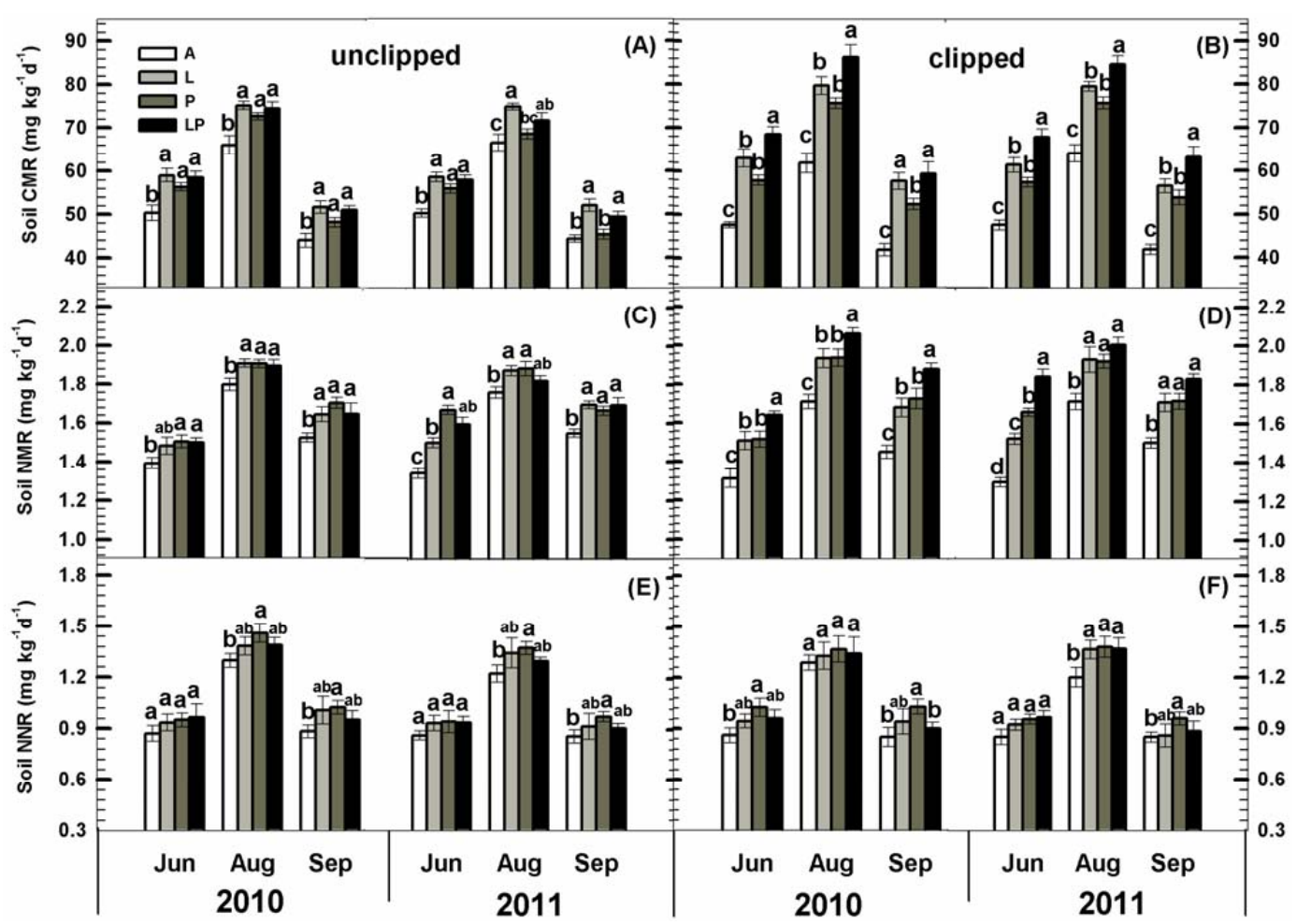

Fig. 5. Seasonal dynamics of soil $\mathrm{C}$ mineralization rate (CMR), net $\mathrm{N}$ mineralization rate (NMR) and net nitrification rate (NNR) under belowground particulate litter addition $(+60 \%)$, increased precipitation $(+30 \%)$ and clipping in the temperate steppe of northeastern China. Values show the monthly means in 2010 and 2011. Vertical bars indicate standard error of means $(n=6)$. Different lowercase letters indicate statistically significant differences $(P<0.05)$. See Fig. 2 for abbreviations.

mechanisms may contribute to the synergistic effects. First, in the clipped plots, BPL addition could supply more available energy and nutrients to soil microorganisms without plant uptake, and subsequently could exert larger priming effects on soil CMR and NMR in the temperate steppe.

Second, BPL addition induced alteration in the microbial community structure under clipped plots, which may partly contribute to the observed synergistic effects. In this study, the negative linear correlations between soil CMR (and NMR) and F:B across the two growing seasons support above findings (Table 3). The relatively lower soil F: B mainly due to the strong increase in bacterial biomass, especially gram-negative bacteria (Fig. 4f), may accelerate soil CMR and NMR. Comparatively, bacteria tend to store less of the $\mathrm{C}$ and $\mathrm{N}$ they metabolize than fungi (Bailey et al., 2002). The main component of bacterial membranes is phospholipids, while two components of fungal cell walls are the polymers of melanin and of chitin. The phospholipids are energy-rich, readily decomposable substrates, whereas the polymers are much more resistant to degradation. Consequently, the decreases in soil F: B likely alters the decomposition process from a slower fungal-based channel to a faster bacterial-based channel (Zhang et al., 2005).

Third, the synergistic effect could have been partly attributed to the interactive effect between clipping and
BPL addition on soil arbuscular mycorrhizal fungi (AMF) biomass. Being a major component of soil microbial biomass (a second subset of fungi), AMF, also plays a distinct and unique role in soil $\mathrm{C}$ and $\mathrm{N}$ sequestration (Rillig et al., 2001; Kaiser et al., 2011). This group, which symbiotically colonizes plant roots, forms associations with $80 \%$ of plant species (Smith and Read, 1997). Plants allocate an estimated 10-20\% of net photosynthate to AMF. AMF hyphae produce glomalin, a recalcitrant glycoproteinaceous substance highly directly correlated with soil aggregate stability (Jastrow and Miller, 1997; Steinberg and Rillig, 2003). Additionally, AMF hyphae together with fine roots create a "sticky-string bag" that enmeshes and entangles soil particles, helping to stabilize macroaggregates (Miller and Jastrow 2000). Here we presented evidence that BPL addition significantly increased soil AMF biomass in unclipped plots but showed no effect in clipped plots (Fig. 4k, 1). Therefore, the relatively lower AMF biomass likely contributes to a higher $\mathrm{C}$ and $\mathrm{N}$ mineralization in this study.

Increased precipitation interacted with clipping also causing synergistic effects on soil CMR and NMR (Fig. 5b, d), as the increases in CMR and NMR were significantly larger than would be expected if the two factors acted additively during the two growing seasons. The most probable explanation for the synergistic effect is also attributed to the shift in 
soil microbial community structure. In this experiment, increased precipitation enhanced soil $\mathrm{F}: \mathrm{B}$ in unclipped plots after the two growing seasons, whereas it significantly decreased soil F: B in clipped plots. The relatively lower soil $\mathrm{F}: \mathrm{B}$ due to the rapid increase in soil gram-positive bacterial biomass (Fig. 4h, j) may contribute to the higher soil CMR and NMR.

In addition, there were significant antagonistic effects between BPL addition and increased precipitation on soil CMR, NMR and NNR $(P<0.01$, Table 2$)$, which could be largely explained by the rapid decrease in soil moisture in the combined BPL addition and increased precipitation treatment $(P<0.05$, Table 2 , Fig. $2 \mathrm{c})$. The strong positive response of aboveground plant biomass, especially dominant species (Stipa baicalensis and Leymus chinensis) (Ma et al., 2012), may lead to more evapotranspiration by local plants and thus partly suppressing the positive precipitation effects on soil $\mathrm{C}$ and $\mathrm{N}$ mineralization under BPL addition plots.

Lack of replication in clipping treatments mean that results of this aspect of our study are statistically not as robust as the other treatments. Future experiments should include clipping into the randomized block design, particularly if vegetation shows a degree of spatial heterogeneity.

Taken together, our results indicate that belowground litter addition, increased precipitation, clipping, and their interactions significantly affected soil $\mathrm{C}$ and $\mathrm{N}$ mineralization in the temperate steppe. These results suggest the importance of plants in mediating the responses of soil $\mathrm{C}$ and $\mathrm{N}$ mineralization to potentially enhanced litter input and precipitation by controlling belowground photosynthate allocation in the temperate steppe. The findings have important implications for constructing mechanistic models of $\mathrm{C}$ and $\mathrm{N}$ cycling under the influence of climatic change and human activity, and for improving prediction of $\mathrm{C}$ and $\mathrm{N}$ sequestration potential and its feedbacks to climate change in temperate steppe ecosystems.

Acknowledgements. The authors acknowledge the funding provided by the Natural Science Foundation of China (30590382, 30570273 and 31300440); the Chinese Academy of Agriculture Sciences and Hulunber Grassland Ecosystem Observation and Research Station for help with logistics and access permission to the study site; and two anonymous reviewers for their constructive comments which helped in improving the manuscript.

Edited by: J.-A. Subke

\section{References}

Aber, J. D., McDowell, W., Nadelhoffer, K. J., Magill, A., Berntson, G., Kamakea, M., McNulty, S., Rustad, L., and Fernandez, I: Nitrogen saturation in temperate forest ecosystems, BioScience, 48 , 921-934, 1998.

Atkinson, D.: Plant root growth, London, UK, Blackwell scientific publications, 1991.
Bailey, V. L., Smith, J. L., and Bolton Jr., H.: Fungal-to-bacterial ratios in soils investigated for enhanced $\mathrm{C}$ sequestration, Soil Biol. Biochem., 34, 997-1007, 2002.

Boggs, L. C., Pikul Jr., J. L., Vigil, M. F., and Riedell, W. E.: Soil nitrogen mineralization influenced by rotation and nitrogen fertilization, Soil Sci. Soc. Am. J., 64, 2038-2045, 2000.

Bossio, D. A. and Scow, K. M.: Impacts of carbon and flooding on soil microbial communities: phospholipid fatty acids profiles and substrate utilization patterns, Microbial. Ecol., 35, 265-278, 1998.

Bossuyt, H., Denef, D., Six, J., Frey, S. D., Merckx, R., and Paustian, K.: Influence of microbial populations and residue quality on aggregate stability, Appl. Soil Ecol., 16, 195-208, 2001.

Busse, M. D., Sanchez, F. G., Ratcliff, A. W., Butnor, J. R., and Carter, E. A.: Soil carbon sequestration and changes in fungal and bacterial biomass following incorporation of forest residues, Soil Biol. Biochem., 41, 220-227, 2009.

Carter, M. R., Angers, D. A., Gregorich, E. G., and Bolinder, M. A.: Characterizing organic matter retention for surface soils in eastern Canada using density and particle size fractions, Can. J. Soil Sci., 83, 11-23, 2003.

Collins, S. L., Sinsabaugh, R. L., Crenshaw, C., Green, L., PorrasAlfaro, A., Stursova, M., and Zeglin L. H.: Pulse dynamics and microbial processes in aridland ecosystems, J. Ecol., 96, 413420, 2008.

Chapman, S. K., Langley, J. A., Hart, S. C., and Koch, G. W.: Plants actively control nitrogen cycling: uncorking the microbial bottleneck, New Phytol., 169, 27-34, 2006.

Chung, H., Grove, J., and Six, J.: Indications for soil carbon saturation in a temperate agroecosystems, Soil Sci. Soc. Am. J., 72, 1132-1139, 2008.

Drenovsky, R. E., Vo, D., Graham, K. J., and Scow, K. M.: Soil water content and organic carbon availability are major determinants of soil microbial community composition, Microbial. Ecol., 48, 424-430, 2004.

Feng, W., Zou, X. M., and Schaefer, D.: Above- and Belowground carbon inputs affect seasonal variatons of soil microbial biomass in a subtropical monsoon forest of southwest China, Soil Biol. Biochem., 41, 978-983, 2009.

Frostegård, A., Bååth, E., and Tunlid, A.: Shifts in the structure of soil microbial communities in limed forests as revealed by phospholipid fatty acid analysis, Soil Biol. Biochem., 25, 723-730, 1993.

Frostegård, A. and Bååth, E.: The use of phospholipid fatty acid analysis to estimate bacterial and fungal biomass in soil, Biol. Fert. Soils, 22, 59-65, 1996.

Gao, Q. and Yu, M.: A model of regional vegetation dynamics and its application to the study of Northeast China Transect (NECT) responses to global change, Global Biogeochem. Cy., 12, 329344, 1998.

Gill, R. A., Polley, H. W., Johnson, H. B., Anderson, L. J., Maherall, H., and Jackson, R. B.: Nonlinear grassland responses to past and future atmospheric $\mathrm{CO}_{2}$, Nature, 417, 279-282, 2002.

Harris, J.: Soil microbial communities and restoration ecology: facilitators or followers? Science, 325, 573-574, 2009.

Hogberg, P. and Read, D. J.: Towards a more plant physiological perspective on soil ecology, Trends Ecol. Evol., 21, 548-554, 2006. 
Hu, S. and van Bruggen, A. H. C.: Microbial dynamics associated with multiphasic decomposition of 14C-labeled cellulose in soil, Microbial. Ecol., 33, 134-143, 1997.

Hu, S., Chapin III, F. S., and Firestone, M. K.: Nitrogen limitation of microbial decomposition in a grassland under elevated $\mathrm{CO}_{2}$, Nature, 409, 188-191, 2001.

IPCC (Intergovernmental Panel on Climate Change). Climate change 2007: the science of climate change, Cambridge University Press, New York, 2007.

Jastrow, J. D. and Miller, R. M.: Soil aggregate stabilization and carbon sequestration: feedbacks through organomineral associations, in: Soil Processes and the Carbon Cycle, edited by: Lal, R., Kimble, J. M., Follett, R. F., and Stewart B. A., CRC Press, Boca Raton, 207-223, 1997.

Jastrow, J. D., Miller, R. M., and Lussenhop, J.: Contributions of interacting biological mechanisms to soil aggregate stabilization in restored prairie, Soil Biol. Biochem., 30, 905-916, 1998.

Jastrow, J. D., Miller, R. M., Matamala, R., Norby, R. J., Boutton, T., Rice, C. W., and Owensby, C. O.: Elevated atmospheric carbon dioxide increases soil carbon, Global Change Biol., 11, 20572064, 2005.

Jin, H. M., Sun, O. J. S., and Liu, J. F.: Changes in soil microbial biomass and community structure with addition of contrasting types of plant litter in a semiarid grassland ecosystem, J. Plant Ecol., 3, 209-217, 2011.

Jones, M. B. and Donnelly, A.: Carbon sequestration in temperate grassland ecosystems and the influence of management, climate and elevated $\mathrm{CO}_{2}$, New Phytol., 164, 423-439, 2004.

Kaiser, C., Koranda, M., Kitzler, B., Fuchslueger, L., Schnecker, J., Schweiger, P., Rasche, F., Zechmeister-Boltenstern, S., Sessitsch, A., and Richter, A.: Belowground carbon allocation by trees drives seasonal patterns of extracellular enzyme activities by altering microbial community composition in a beech forest soil, New Phytol., 187, 843-858, 2010.

Kaiser, C., Fuchslueger, L., Koranda, M., Gorfer, M., Stange, C. F., Kitzler, B., Rasche, F., Strauss, J., Sessitsch, A., Boltenstern, S. Z., and Richter, A.: Plants control the seasonal dynamics of microbial $\mathrm{N}$ cycling in a beech forest soil by belowground $\mathrm{C}$ allocation, Ecology, 92, 1036-1051, 2011.

Kaye, J. P. and Hart, S. C.: Competition for nitrogen between plants and soil microorganisms, Trends Ecol. Evol., 12, 139-143, 1997.

Kim, D. G., Vargas, R., Bond-Lamberty, B., and Turetsky, M. R.: Effects of soil rewetting and thawing on soil gas fluxes: a review of current literature and suggestions for future research, Biogeosciences, 8, 9847-9899, 2011, http://www.biogeosciences.net/8/9847/2011/.

Lal, R.: Carbon sequestration. Phil. Trans. R. Soc. B, 363, 815-830, 2008.

Liu, W. X., Xu, W. H., Hong, J. P., and Wan, S. Q.: Interannual variability of soil microbial biomass and respiration in responses to topography, annual burning and $\mathrm{N}$ addition in a semiarid temperate steppe, Geoderma, 158, 259-267, 2010.

Lovell, R. D., Jarvis, S. C., and Bardgett, R. D.: Soil microbial biomass and activity in long-term grassland: Effects of management changes, Soil Biol. Biochem., 27, 969-975, 1995.

Ma, L. N., Lü, X. T., Liu, Y., Guo, J. X., Zhang, N. Y., Yang, J. Q., and Wang, R. Z.: The effects of warming and nitrogen addition on soil nitrogen cycling in a tem- perate grassland, northeastern China, PLoS One, 6, e27645, doi:10.1371/journal.pone.0027645, 2011.

Ma, L. N., Huang, W. W., Guo, C. Y., Wang, R. Z., and Xiao, C. W.: Soil microbial properties and plant growth responses to carbon and water addition in a temperate steppe: the importance of nutrient availability, PLoS One, 7, e35165, doi:10.1371/journal.pone.0035165, 2012.

Manzoni, S. and Porporato, A.: Soil carbon and nitrogen mineralization: Theory and models across scales, Soil Biol. Biochem., 41, 1355-1379, 2009.

McIntyre, R. E. S., Adams, M. A., Ford, D. J., and Grierson, P. F.: Rewetting and litter addition influence mineralization and microbial communities in soils from a semi-arid intermittent stream, Soil Biol. Biochem., 41, 92-101, 2009.

Miller, R. M. and Jastrow, J. D.: Mycorrhizal fungi influence soil structure, in: Arbuscular mycorrhizas: physiology and function, Kluwer Academic, edited by: Kapulnik, Y. and Douds, D. D., Dordrecht, the Netherlands, 3-18, 2000.

Ni, J. and Zhang, X. S.: Climate variability, ecological gradient and the Northeast China Transect (NECT), J. Arid Environ., 46, 313 325,2000

Olsson, P. A., Francis, R., Read, D. J., and Söderström, B.: Growth of arbuscular mycorrhizal mycelium in calcareous dune sand and its interaction with other soil microorganisms as estimated by measurement of specific fatty acids, Plant Soil, 201, 9-16, 1998.

Olsson, P. A., Thingstrup, I., Jakobsen, I., and Bååth, E.: Estimation of the biomass of arbuscular mycorrhizal fungi in a linseed field, Soil Biol. Biochem., 31, 1879-1887, 1999.

Paul, E. A. (Ed.): Soil Microbiology, ecology and biochemistry, Elsevier, New York, 532 pp., 2007.

Parton, W. J., Ojima, D. S. and Schimel, D. S.: Models to evaluate soil organic matter storage and dynamics, in: Structure and Organic Matter Storage in Agricultural Soils, edited by: Carter, M. R. and Stewart, B. A., CRC Press, 420-448, 1996.

Raison, R. J., Connell, M. J., and Khanna, P. K.: Methodology for studying fluxes of soil mineral-N in situ, Soil Biol. Biochem., 19, 521-530, 1987.

Reinhardt, D. R. and Miller, R. M.: Size classes of root diameter and mycorrhizal fungal colonization in two temperate grassland communities, New Phytol., 116, 129-136, 1990.

Rillig, M. C., Wright S. F., Nichols K. A., Schmidt W. F., and Torn M. S.: Large contribution of arbuscular mycorrhizal fungi to soil carbon pools in tropical forest soils, Plant Soil, 233, 167-177, 2001.

Rinnan, R., Michelsen, A., and Jonasson, S.: Effects of litter addition and warming on soil carbon, nutrient pools and microbial communities in a subarctic heath ecosystem, Appl. Soil Ecol., 39, 271-281, 2008

Six, J., Conant, R. T., Paul, E. A., and Paustian, K.: Stabilization mechanisms of soil organic matter: Implications for C-saturation of soils, Plant Soil, 241, 155-176, 2002.

Smith, S. D., Monson, P. K., and Anderson, J. E.: Physilogicical ecology of north American desert plants, New York, SpringerVerlag, 1997.

Sollins, P., Spycher, G., and Glassman, C. A.: Net nitrogen mineralization from light- and heavy-fraction forest soil organic matter, Soil Biol. Biochem., 16, 31-37, 1984.

Sparling, G. P., Murphy, T., Thompson, L., and Fillery, I. R.: Shortterm net $\mathrm{N}$ mineralization from plant residues and gross and net 
$\mathrm{N}$ mineralization from soil organic matter after rewetting of a seasonally dry soil, Aust. J. Soil Res., 33, 961-973. 1995.

Steinberg, P. D. and Rillig, M. C.: Differential decomposition of arbuscular mycorrhizal fungal hyphae and glomalin, Soil Biol. Biochem., 35, 191-194, 2003.

Stewart, C. E., Paustian, K., Conant, R. T., Plante, A. F., and Six, J.: Soil carbon saturation: Concept, evidence and evaluation, Biogeochemistry, 86, 19-31, 2007.

Suberkropp, K. and Weyers, H.: Application of fungal and bacterial production methodologies to decomposing leaves in steams, Appl. Environ. Mocrob., 62, 1610-1615, 1996.

Tu, C., Ristaino, J. B., and Hu, S.: Soil microbial biomass and activity in organic tomato farming systems: effects of organic inputs and straw mulching, Soil Biol. Biochem., 38, 247-255, 2006.

Wardle, D. A., Bardgett, R. D., Klironomos, J. N., Setälä, H., van der Putten, W. H., and Wall, D. H.: Ecological linkages between aboveground and belowground biota, Science, 304, 1629-1633, 2004.

Wang, C. H., Wan, S. Q., Xing, X. R., Zhang, L., and Han, X. G.: Temperature and soil moisture interactively affected soil net $\mathrm{N}$ mineralization in temperate grassland in Northern China, Soil Biol. Biochem., 38, 1101-1110, 2006.
Weltzin, J. F., Loik, M. E., Schwinning, S., Williams, D. G., Fay, P., Haddad, B., Harte, J., Huxman, T. E., Knapp, A. K., Lin, G., Pockman, W. T., Shaw, M. R., Small, E. E., Smith, M. D., Smith, S. D., Tissue, D. T., and Zak, J.: Assessing the response of terrestrial ecosystems to potential changes in precipitation, BioScience, 53, 941-52, 2003.

Xia, J. Y., Niu, S. L., and Wan, S. Q.: Response of ecosystem carbon exchange to warming and nitrogen addition during two hydrologically contrasting growing seasons in a temperate steppe, Global Change Biol., 15, 1544-1556, 2009.

Xiao, C. W., Janssens, I. A., Liu, P., Zhou, Z. Y., and Sun, O. J.: Irrigation and enhanced soil carbon input effects on below-ground carbon cycling in semiarid temperate grasslands, New Phytol., 174, 835-846, 2007.

Zhang, W., Parker, K. M., Luo, Y., Wan, S., Wallace, L. L., and $\mathrm{Hu}, \mathrm{S}$.: Soil microbial responses to experimental warming and clipping in a tallgrass prairie, Global Change Biol., 11, 266-277, 2005.

Zhu, T. C.: Yang-Cao biological ecology, Jilin Science and Technology Press, Jilin, 2004. 